\title{
Linguistic Choices in Hamid's Moth Smoke: A Transitivity Analysis
}

\author{
Hafiz Muhammad Qasim ${ }^{1}$, Mubina Talaat ${ }^{1}$, Qamar Khushi ${ }^{1}$ \& Musarrat Azher ${ }^{2}$ \\ ${ }^{1}$ Department of English, Bahauddin Zakariya University, Multan, Pakistan \\ ${ }^{2}$ Departments of English, University of Sargodha, Sargodha, Pakistan \\ Correspondence: Hafiz Muhammad Qasim, Department of English, Bahauddin Zakariya University, Multan, \\ Pakistan. E-mail: m_qasim@hotmail.com
}

Received: January 18, 2018 Accepted: February 12, 2018 Online Published: February 21, 2018

doi:10.5539/ijel.v8n3p303 URL: http://doi.org/10.5539/ijel.v8n3p303

\begin{abstract}
The present study is aimed at an investigation of how meanings are construed in a literary text. The main theoretical framework employed for the data analysis was transitivity, which finds its roots in Halliday's (1994) Systemic Functional Grammar. 21 texts from Hamid's novel, Moth Smoke (MS) were selected as data. A sample size of 1100 complex clause sentences containing different processes, participants and circumstances was drawn for analysis. The focus of the study was the identification of transitivity patterns associated with the main characters of the novel following Simpson (2004) who viewed it "useful indicator of character in prose fiction" (p. 119). The findings of transitivity constructions showed that all types of processes were found in MS. Based on the rank of frequency, material processes were computed the most frequent processes. They did have frequency of occurrence as $(1076=51.45 \%)$. The projection of mental processes was $(13.91 \%)$ in the second position. The verbal processes were $(11.23 \%)$, relational processes $(19.75 \%)$ while the lowest projection was found in behavioural $(2.63 \%)$ and existential $(0.86 \%)$ processes. Male characters were ascribed with more material and verbal processes while females were drawn as having mental and attributive process clauses. The current study concluded that transitivity options can function as a useful analytical tool in the analysis of a literary text.
\end{abstract}

Keywords: systemic functional linguistics, transitivity, ideational metafunction, Moth Smoke (MS), ideology

\section{Introduction}

The present study is carried out: i) to investigate how meanings are construed in a literary text, ii) to identify transitivity patterns associated with the main characters of Hamid's novel, MS and iii) to explore how the system of transitivity is employed by the author to convey his ideology to the readers. It is also concerned with the study of participants' roles in the novel under study. The main theoretical framework employed for the data analysis was transitivity, which finds its roots in Halliday's (1994) systemic functional grammar.

\section{Background of the Novel}

MS (2002) is based on the story of Darashikoh Shezad (Daru), an orphan, but a brilliant student of Lahore's elite Government College. His father died of gangrene in the Bangladesh war and his mother was killed with a starry bullet of Kalashnikov fired during a wedding ceremony (Pande, 2000). The names of the characters of the novel have been borrowed from the Mughal history, but they are not fit enough to their namesake and the analogy (Desai, 2000). Daru, the protagonist hankers after power, pelf and luxuries of life. He loses his well-paid job as a result of an exchange of words with a big gun, a feudal lord, and falls into an economic crisis. Despite falling into bad days, he continues to stick to the rich patterns of living which he can ill-afford. He falls in love with his best friend, Aurangzeb (Ozi)'s wife, Mumtaz. Daru complicates the matter by developing a sexual relationship with her. He does so when he is disappointed in Ozi on crushing an innocent poor boy in a reckless driving. Meanwhile, he even starts selling narcotics to keep his life going. Furthermore, he joins hands with Murad in a robbery plan to rob a boutique, but unluckily he kills a boy in the process. In the end, Ozi takes revenge by getting him arrested for his own crime of crushing a boy, using his wealth and corrupt system. The novel comprises strong implications. As an allegory, it describes the state of affairs in Pakistan. It "exposes the social disparity in Pakistani urban society and comments on the unequal distribution of wealth as a means of shaping the lives of the people belonging to different strata of society" (Tariq, 2008, p. 107).

Like every writer, Hamid's style of writing novels is different and he has a uniqueness of meaning as Halliday 
(1976) puts "every work achieves a unique balance among the types and components of meaning and embodies the writer's individual exploration of the functional diversity of language" (p. 360). He leaves the choice for the readers. So, the readers read the novels differently and they base their interpretation on their interest and knowledge about the settings of the novels. The selected texts have been analyzed according to the transitivity choices, which may enhance the readers' perception.

\section{Literature Review}

\subsection{Theoretical Framework: Transitivity System}

Social actors and other entities are represented in texts by means of the transitivity system, a semantic concept (Haig, 2012, p. 48). It is generally referred to how meaning is structured and represented in a clause. As a source of transmission of ideas and meanings, it is considered to fall in the domain of the ideational function of language (Fowler, 1986). According to Halliday (1985), it is the part of ideational function of the clause, and the ideational function of the clause is concerned with the transmission of ideas, i.e. representing processes or experiences, actions, events and the processes of consciousness and relations. According to Matthiessen \& Halliday (1997), "the ideational metafunction engenders resources for constructing our experience of the world around us and inside us; the ideational system at clause rank is transitivity" (p. 15). It consists of two modes: process types (transitive) and agency (ergative). Transitivity is concerned with construal of experience by different processes, whereas ergative system is concerned with understanding of meaning from a general perspective in the sense that processes are either caused or not caused by any external agency. Transitivity, thus, is concerned with a coding of the goings on: who does what in relation to whom /what, where when, how and why. The transitivity analysis is related to identification of the process, its participants and circumstances "pertinent to the process-participants configuration" (Hasan, 1988, p. 63). Halliday (1985) opined the same:

Our most powerful concern of reality is that it consists of "going on: of doing, happening, feeling and being." These goings on are sorted out in the semantic system of the language, and expressed through the grammar of clause... the clause involved simultaneously in another grammatical function expressing the reflective, experiential aspect of meaning. This is the system of transitivity. Transitivity specifies the different types of processes that are recognized in the language, and the structures by which they are expressed (p. 101).

Every clause has three components namely i) process (material, mental, verbal, behavioral, relational and existential), ii) the participants (doer, senser, sayer, behaver, carrier/ token and existent), and iii) the circumstances associated with the process. The term "process" covers "all phenomena... and anything that can be expressed by a verb: event, whether physical or not, state or relation" (Halliday, 1976, p. 159). The process can be classified according to the criterion whether it represents action (material process: process of doing), speech (verbal process: process of saying), mental state (mental process: process of sensing), state of being (relational process: process of being), behaving (behavioral process) or existing (existential process).

Material processes are processes of happening and doing. Material processes have an actor or medium as a participant. An actor is the "entity to which something happens or is done" (Toolan, 1998, p. 79). The following examples (taken from MS) clarify the notion:

(i) The guard (Actor) walks (Process: Material), (ii) I (Actor) shut (Process: Material) my eyes (Goal), (iii) My elbows (Actor) tucked (Process: Material), (iv) And a shadow (Actor) falls (Process: Material) like blindness (Circumstance: Manner) over the shadows (Circumstance: Location) in the cell (Circumstance: Location), (Action is shown by human in (i) and (ii) and by human body part in (iii) or non-human in (iv).

Other participants of the material process are: goal, range, beneficiary and recipient. The examples (i-iv) mentioned above, provide a clear picture of beneficiary, goal and recipient. (i) And a servant (Actor) leads (Process: Material) me (Recipient) inside and upstairs (Range) (MS, p. 11-16), (ii) Why (Circumstance: Cause) don't you (Actor) take (Process: Material) him (Goal) to bed (Range) (MS, p. 44-47), (iii) I (Actor) escort (Process: Material) him (Goal) to my BM's office (Range) (MS, p. 19-24), (iv) He (Actor) gave (Process: Material) me (Beneficiary) a silver bracelet (Goal), (MS, p. 48-52) (v) We (Actor) met (Process: Material) for tea and talk (Circumstance: Cause) on Tuesdays (Circumstance: Location) after which (Circumstance: Location) I (Actor) gave (Process: Material) him (Recipient) a ride (gratis) (Goal) (MS, p. 61-62).

Mental processes tell us how people think, feel and understand. The participant that thinks, feels or perceives something, is termed as senser and that which is felt, thought or perceived by the conscious senser, is called Phenomenon. The following examples describe mental processes:

(i) I (Senser) know (Process: Mental) the identity of Zulfikar Manto (Phenomenon) (MS, p. 44-47), (ii) Mumtaz 
(Senser) assumes (Process: Mental) a mock-serious expression (Phenomenon) (iii) but I (Senser) 'm already (Circumstance: Location) imagining (Process: Mental) an elaborate rescue scenario (Phenomenon) (MS, p. 44-47).

The behavioral process describes unintentional actions, reactions or doings performed by humans. It has only one participant, the behaver. For example, She (Behaver) nods (Process: Behavioural) once (Circumstance: Location); She (Behaver) smiles (Process: Behavioural) (MS, p. 44-47). Verbal processes include the verbs like "communicate, report, say, tell". It includes i) sayer, ii) verbiage and iii) receiver or addressee as participants. For example, (i) (Get out (Process: Material) (Verbiage) says (Process: Verbal) the mustache (Sayer), (ii) Please tell (Process: Verbal) me (Receiver) what check (Verbiage) (MS, p. 19-24).

Relational processes are describing verbs. The linking verbs represent these processes. According to Eggins (2004), it is divided into two major types i) attributive and ii) identifying processes. Other kinds of relational process include i) possessive and ii) circumstantial. The relational attributive process has two participants i) carrier and ii) attribute, whereas participants in identifying process are i) token (identified) and ii) value (identifier) and in the relational possessive process i) possessor and ii) possessed. For example, (i) and suddenly (Circumstance: Manner) $I$ (Carrier) ' $m$ (Process: Relational: Attributive) upset (Attribute) (MS, p. 44-47) (ii) She (Token)'s (Process: Relational: Identified) a moth (Value) as well (Circumstance: Manner) circling (Process: Material) me (Goal) (MS, p. 203-5) (iii) I (Actor) didn't lie (Process: Material), didn't pretend (Process: Mental) I (Possessor) hadn't had (Process: Relational: Possessive) an affair (Possessed) (MS, p. 243-44).

Existential process is identified as the structure that involves the word "there". This existential "there" according to Eggins (2004, p. 214), has no representational meaning: location. It employs the verb "be" or its synonyms. It has only one participant, the Existent. For example, and then (Circumstance: Location) there is (Process: Existential) quiet (Existent) (MS, p. 5-6).

Circumstance is realized by circumstantial adjuncts. The circumstance extent deals with how the process extends in space and time while location, circumstance construes the location of the process in space and time, e.g. how many years (Circumstance: Extent) you (Goal) will be shut (Process: Material) in prison (Circumstance: Location) (MS, p. 16-17). The manner circumstance deals with how the process is realized. For example, $I$ (Actor) need to present (Process: Material) my case (Goal) forcefully (Circumstance: Manner) (MS, p. 19-24). The cause circumstance shows the reason that the process is realized. For instance, the rest of us (Carrier) are (Process: Relational: Attributive) idiots (Attribute) for settling (Circumstance: Cause) for jobs (Circumstance: Cause) (MS, p. 44-47). The contingency circumstance specifies an element on which the actualization of the process depends. For example, although (Circumstance: Contingency) I (Senser) doubt (Process: Mental) it (Phenomenon) (MS, p. 48-52). The accompaniment circumstance represents the meanings "and", "or", "not" as circumstantial e.g., It (Actor) so (Circumstance: Manner) happened (Process: Material) that on one rainy day (Circumstance: Location) an occasional client of mine, the inimitable Professor Julius Superb (Actor) brought (Process: Material) one of his favorite students (Goal) into my rickshaw (Circumstance: Location) with him (Circumstance: Accompaniment) (MS, p. 61-62). The role circumstance represents the meaning of be or become. The example is "and he (Actor) embraced (Process: Material) Darashikoh (Goal) as a partner (Circumstance: Role) when (Circumstance: Location) the latter (Actor) fell (Process: Material) from cooling (Circumstance: Location)" (MS, p. 104-105). The Matter circumstance may be probed by the interrogative "what about? And she (Actor) presses (Process: Material) against my side (Circumstance: Matter)” (MS, p. 201-3). The angle circumstance represents the source or viewpoint of the process, e.g. and I (Possessor) don't have (Process: Relational: Possessive) the money (Possessed) (to buy (Process: Material) fuel (Goal) for it (Beneficiary)) in any case (Circumstance: Angle) (MS, p. 90-91).

The Transitivity model provides us a viable framework for revealing the main linguistic features of the novel under study. It plays a pivotal role in showing how the author encodes through language choice, his mental picture of reality and how he accounts for his experience of the world around him. In other words, it helps in evaluating language used by the author and highlighting how he construes ideology through foregrounding specific linguistic choices in his writings.

\subsection{Previous Studies in the Field}

There are a number of significant research studies on Systemic Functional Linguistics (SFL) and Grammatical Metaphor (GM) aiming to investigate political, literary or other discourses in various veins and genres as follows.

In their studies, Kazemian, Behnam, \& Ghafoori (2013) and Kazemian \& Hashemi (2014) adopted Hallidayan Systemic Functional Grammar to pinpoint and analyze nominalization and the role played by it in a corpus of 10 
authentic scientific texts drawn from very influential magazines; the analysis was based on nominalization, its frequency and process types. The analysis displayed that Ideational GM permeated scientific texts and the prevailing process types were material and relational types. Consequently, the tone of the writing was more abstract, technical and formal.

In some other veins, Kazemian \& Hashemi $(2014,2017)$ introduced an integrated approach to analyze political or other discourses in light of overarching methodological frameworks of Hallidayan GM in SFL, and Fairclough's perspective on critical discourse analysis and Rhetoric. They analyzed Mr. Obama's eight speeches from the point of frequency and functions of Nominalization, Rhetorical strategies, Passivization and Modality etc. to manifest the integrated approach practicality and adeptness through analysis; then by virtue of analysis to unveil how language was manipulated and distorted by orators in order to convey seamlessly intended messages and political creeds to the audience.

Surveying the recent annals of literature, some other remarkable studies also investigated various political, advertisement, etc. discourses in light of SFL and GM to discern multiple strategies exploited by orators and political pundits and the way they made text/talk persuasive, significant, appealing and obscure, as well as the way they conveyed their intended objectives to the audience (Cap \& Okulska, 2013; Devrim, 2015; Noor et al., 2015 etc.).

Kennedy (1982), following Halliday, analyzed the transitivity patterns used in the novel, especially in the climactic scene. He analyzed how transitivity can be related to depicting the main players and characterization in the novel under study. He asserted that the transitivity model would prove a valuable approach to textual analysis (Kennedy, 1982, p. 86). He concluded that transitivity choices define the roles of participants in a situation and help us arrive at understanding the reasons for the actions of the participants. Hasan's (1989, 1985 \& 2011) study of Murray's poem showed that the verbal processes were not existent in the poems and the material processes dominated other five processes as the number of mental processes in the poem was only one. She thought that the old was involved in the processes due to the absence of other participants. Her role was more dynamic (Samimi, 2013). She argued that "part of the basis of our perception of what a person is like derives from knowing what sort of participant roles is ascribed to that person" (Hasan, 2011, p. 449).

Gallardo's (2006) work on Shaw's (1913) novel Pygmalion was exemplary. He used transitivity technique to investigate the social class system and gender. The analysis showed that male and female characters (like Eliza Doolittle \& Henry Higgins) used language differently, which represented their distinguished traits. He concluded that male characters used the material process types, which were concerned with rational matters and had a clear goal to assign them a powerful role in the society and in contrast female characters were involved in emotional linguistic choices, that was, mental processes. It showed their tender feelings, emotions, intimacy, and affection. The writer's analysis further proved the power of language in depicting ideology, worldview, and reality.

Mwinlaaru (2012) investigated transitivity patterns associated with six characters of Chinua Achebes' novel Anthills of the Savannah. The writer investigated the relationship between point of view and the transitivity patterns in which a character was inscribed. The transitivity choices on the part of the writer revealed variations in the presentation of characters. The study demonstrated the interplay between the characters and linguistic choices. The protagonist, Sam was presented, as authoritative political leader through the use of material processes and circumstantial elements. Mwinlaaru (2012) asserted that model of transitivity is suitable for stylistic analysis of literary texts.

Simic (2013) investigated the un-actualized participants of processes in English to Serbian translations, through a corpus tool. To him, awareness of the complexities of translation of construction of process participants among the students can be beneficial in the process of translation and interpretation and it will contribute to their fluency and quality in their work. He suggested five steps for teaching elements of process, and especially un-actualized participants. His study was based on how the problem of un-actualized process participants was treated in English and Serbian translations, similarities, and dissimilarities between these translations.

The following lines present some representative studies on Hamid's MS. Lahiri (2000) in his article Money Talks in Pakistan concluded that the plot of the novel was a socio-economic triangle: Ozi, Daru, and a poor boy run over by Ozi's Pajero. The author made a comparison between stories of MS and The Great Gatsby by Fitzgerald (1925), as the events showed messes created by the rich and cleaned up by the poor. The author ascribed Daru's personality-imbalance to the economic disparity faced by him in the society he lived in. Similarly, Gehr's (2000) article Nuclear Burnout commented on the taut construction, dense similes and historical resonance of a grimly amusing novel about sex, drugs and class warfare in postcolonial Asia. Like Lahiri, Gehr also compared MS with Spillane's (1952) Kiss Me Deadly, for Daru's resentment towards the elite class, and the tension between 
Pakistan and India caused by the nuclear tests.

In his study, Greenwood (2000) showed Daru's bitter scorn against wealthy friends. As an archetype, he represented Pakistan that was trying to catch up to India and dominated the regional strategic equation with nuclear tests without thinking about the bad economic consequences. The author showed the writer's portrayal of the solidarity of Pakistanis- the rich and the poor-in the matter of military urgency. "You just toss the idea of war and get the nation stand united". To the author, the story of the novel was non-linear but organic. Daru made his flaws his charms while other characters overlapped the boundaries between good and evil. Jay's (2005) study concluded that the focus of the novel was on economic globalization whereas other writers' concentration was upon the cultural and identity crisis in a hybridized postcolonial world. To him, Hamid dramatized the transformations brought about by economic globalization to the city. His dealing with economic globalization was fit to theme, as he himself was a beneficiary of America.

Sadiq (2006) analysed point of view and speech and thought presentation in MS. This descriptive study was carried out by selecting some extracts from the novel. The author used Short's (1996) model of stylistic analysis. Her argument in this study was that tense switches from present to past, according to the subject matter and the author allowed all the characters to voice through their direct communication with the reader. Similarly, the artistic use of pragmatic signals contributed to express a point of view of the major characters. She also found that the relations among the characters were based on need not blood. She further pointed out that the narrator's less association with modes of speech and thought presentation reflected the narrator's inability to access the minds of other characters in the novel.

Prior studies have tended to concentrate on some other genres and discourses. This study is unique in the sense that it attempts to bridge the gap among previous studies by analyzing linguistic choices in Hamid's MS to identify transitivity patterns associated with the main characters of the novel. It applied transitivity model for analysis of a much broader range of 21 texts to bring out its importance and the writer's intention by showing a semantically motivated pattern of language choice. The exploration of the characters of the novel is based on the supposition that the language used in the sample texts represents selections made out of the available choices in the linguistic system (Halliday \& Matthiessen, 2004).

\section{Objectives of the Study}

The present study was purposefully designed to investigate how meanings are construed and interpreted applying ideational metafunction in a literary text and identify transitivity patterns associated with the main characters of Hamid's novel, MS following Simpson (2004) who viewed it "useful indicator of character in prose fiction" (p. 119). The study was the exploration of how behaviour of various characters in the novel, their social position, and feelings were constructed and presented through the language used in Hamid's novel.

\section{Methodology}

\subsection{Data Collection}

21 text extracts of Hamid's MS were taken as data. A sample size of 1100 complex clause sentences containing different processes, participants and circumstances was drawn for analysis. The choice of the text was based on typicality, variety, relevance, representativeness and the need of the study. Different segments of the novel were selected, which were referred to as A, B, C, D, E, F, G,H, I J, K, L, M, N, O, P, Q, R, S, T, and U. The selected extracts would contribute to highlight the processes employed by the writer. Table 1 displays the distribution of texts selected for transitivity analysis.

Table 1. A Summary of text samples taken from $M S$

\begin{tabular}{llllllll}
\hline No. & Selected text & Moth Smoke & Page number & No. & Selected text & Moth Smoke & Page number \\
\hline 1 & A & Onset & $5-6$ & 12 & $\mathrm{~L}$ & Chapter-8 & $104-5$ \\
2 & $\mathrm{~B}$ & Chapter-3 & $10-11$ & 13 & $\mathrm{M}$ & Chapter-8 & $106-7$ \\
3 & $\mathrm{C}$ & Chapter-3 & $11-16$ & 14 & $\mathrm{~N}$ & Chapter-9 & $137-39$ \\
4 & $\mathrm{D}$ & Chapter-3 & $16-17$ & 15 & $\mathrm{O}$ & Chapter-10 & $152-53$ \\
5 & $\mathrm{E}$ & Chapter-3 & $19-24$ & 16 & $\mathrm{P}$ & Chapter-10 & 158 \\
6 & $\mathrm{~F}$ & Chapter-5 & $44-47$ & 17 & $\mathrm{Q}$ & Chapter-11 & $171-72$ \\
7 & $\mathrm{G}$ & Chapter-5 & $48-52$ & 18 & $\mathrm{R}$ & Chapter-12 & $184-85$ \\
8 & $\mathrm{H}$ & Chapter-6 & $61-62$ & 19 & $\mathrm{~S}$ & Chapter-13 & $201-3$ \\
9 & $\mathrm{I}$ & Chapter-7 & $80-81$ & 20 & $\mathrm{~T}$ & Chapter-13 & $203-5$ \\
10 & $\mathrm{~J}$ & Chapter-7 & $86-87$ & 21 & $\mathrm{U}$ & Chapter-16 & $243-44$ \\
11 & $\mathrm{~K}$ & Chapter-7 & $90-91$ & & & & \\
\hline
\end{tabular}




\subsection{Data Analysis}

The present study was qualitative as well as quantitative in approach. The descriptive qualitative method explained the given data systematically and quantitative analysis produced frequency indexes and statistically significant results (Creswell, 1994; Mwinlaaru, 2012). The text of Hamid's MS was selected as data. The main theoretical framework employed for the data analysis was transitivity, which found its roots in Halliday's (1994) Systemic Functional Linguistics. In applying Systemic Functional Linguistics to the transitivity analysis of Hamid's MS the present research, partly relied on Eggins (1994), Kennedy (1982), Hasan (1989 \& 2011), Mwinlaaru (2012), Gallardo (2006) and Eggins (1994 \& 2004) in the network of six types of process and circumstance in a clause and frequency indexes of its elements for the analysis of the selected texts. The emphasis was placed on the manner in which processes and participants in processes were represented in the texts (for detail see Qasim, 2016).

\section{Transitivity Choices in Moth Smoke}

\subsection{Analysis of Texts $A-U$}

First, we looked into the frequency of the processes and clauses as a clause has a paramount importance in the realization of the meaning and analysis of any text (Hasan, 1988). The reason for identification and description of processes is that by so doing we can explore if their distribution reflects the asymmetry of power among various participants. Moreover, analysis of verbal art requires matching patterns in the text. Text-A contains 15 sentences, 25 clauses and 42 processes. $27=64.28 \%$ material processes are dominant. It indicates that the text is related to the literary genre and is concerned with the narrative report of physical actions, events involving dynamic and concrete actions that the participants undergo. It is evident that most of the participants are humans, not the abstract entities. The material clauses encompass the presentation of actions by the characters, events and happenings caused by agents, animate and inanimate. The extract focuses on the setting Daru finds him in, and describes his perceptions of the prison and the environment. The abundant use of material clauses foresees the occurrence of some horrors and tragic episodes in the coming chapters of the novel.

$4=.52 \%$ mental clauses project perceptions, emotions and thoughts of the participants. They show the internal and external states of the narrator and that of others mentioned in the text under study. Two behavioural processes (4 and 8ii) show Daru's behaviour and attitude. All 4 relational processes in text-A are attributive. No identifying, possessive or circumstantial clause is found in this text. The relational clauses aim at the description of the persons or things. The attributive clause (my cell is full of shadows) shows the position of the main figure and indicates one important aspect of genre of fiction. The personal possessive pronoun (my) indicates his close relationship with prison (cell) as he seems to be the owner of the prison. This clause also presents the condition of Pakistani society which is full of darkness, gloom and sorrows. Further, it hammers the fact that the narrator is the central figure of the novel while other characters might be of minor significance. First person narrative (I) and personal pronoun (my) have been used to make the narrative more direct and personal. The text shows only one verbal clause 12i (Someone curses). The indefinite pronoun (someone) is not other than Daru himself. It reveals the inner consciousness of the participant involved in the outer world (Halliday \& Matthiessen, 2004).

After the identification of processes it is relevant to know which roles the participants are projected taking up in the processes to see the extent of their power relationship. The participants capture the most important unit of meaning about who or what is involved' that is people, places, things, concepts etc. (Droga \& Humphrey, 2003, p. 29). Text-A contains 19 actors, 13 goals, 2 beneficiaries, 3 sensers, 5 phenomena, 4 carriers, 2 behavers, and only one sayer. Out of these, the -er and -ed (actor and goal) roles are noticeable in text- A. The main participant role is associated with a first person narrator " $P$ " (Daru). He is projected as actor $(26.31 \%)$, senser $(100 \%)$, behaver $(100 \%)$ and carrier $(50 \%)$.

Text-B contains 38 clauses and 53 processes. The analysis realizes the material processes as $(43=81.13 \%$, mental $(1.88 \%)$ one existential, (11.52\%) relational, and (40\%) possessive in this text. There are 12 actor roles, 30 goals, 3 beneficiary roles, one phenomenon, and 3 carrier roles. Text-C comprises 131 complex clauses, 152 simplex clauses and 223 processes. The material processes account for $(107=47.98 \%)$. There are 322 participants in the whole grammatical unit. The major participants are: Ozi, Daru, and Mumtaz. These participants are distributed as 70 actors, 2 agents, 69 goals, 8 beneficiaries, one existent, 2 ranges, 15 sensers, 11 Phenomena, 45 sayers, 7 receivers, 34 carriers of certain attributes, one token, 7 possessors of characteristics, 6 possessed, 40 attributes, 70 verbiages, and 8 behavers. The protagonist of the novel, Daru is portrayed in different roles. He is associated with actor (23.68\%), goal (4.22\%), client (50\%), recipient (50\%), senser $(66.66 \%)$, carrier of attributes and token $(14.70 \%)$, identified possessor of characteristics $(100 \%)$, sayer $(33.33 \%)$, and receiver of verbiages $(28.57 \%)$ and behaver (25\%). 
The linguistic analysis of Text-D indicates that there are 51 complex and 60 simplex clauses, and 136 participants in this extract. The material processes are dominant in this extract. They are $(44=8.88 \%)$ of total 90 processes. Daru is made the subject of action verbs. Out of 136 participants, 44 active roles refer to him. It is interesting that the main character is the dominant participant in the given text. He has projection as a goal (13.33\%), beneficiary/recipient (25\%), senser (80\%), phenomenon $(8.33 \%)$, carrier $(54.54 \%)$, token (100\%), sayer $(23.07 \%)$, and receiver $(100 \%)$. His actor role has received highest frequency. The clauses (1i, 1ii, $2 \mathrm{iii}, 5 \mathrm{iii}$, 5iv, 7, 8, 9, 12, 31, 32,40ii, 43, 26, 40ii, 50i, 50ii, 10, 14, 19, 47, 54) show that he is actor in $28(63.63 \%)$ processes. He is senser in 8 processes. The proportion of relational attributive and mental processes illustrates that the narrator, Daru tries to sketch his relationship, behaviour and inner thoughts towards the environment.

Text-E comprises 168 clauses and 262 processes. It is next to the participants, which are 328. The participant roles are actor (86), goal (85), beneficiary (11), range (2), senser (29), token (1) Phenomenon (26), sayer (29), verbiage (43), receiver (14), carrier (36), attribute (29), existent (2) and behaver (2). The major role revolves around Daru, Jiwan and Bank Manager. The relational attributive processes provide descriptive information qualities of Daru. Out of 37 carrier roles Daru is given $(16=43.24 \%$. 52 material processes are dominantly associated with him. Sometime, there is a possibility of extra participant that causes or initiates action (Gerot \& Wignell, 1994, p. 74). This phenomenon is seen in clause 89ii (And makes me dream wave my hands. This clause is causative and the agent (fear) is ellipsed. Mr. Jiwan is actor in 9 processes. The material and verbal processes associated with Mr. Jiwan construe that the participant belongs to the ruling class.

Text-F contains 133 clauses, 251 participants, 175 processes, and 99 circumstances. The material processes are $(62=35.42)$, mental $(39=22.28 \%)$, and verbal $(27=15.42 \%)$. There are 47 roles of actor in the text and Daru is projected as taking up this role in 8 processes $(17.02 \%)$, followed by $11(28.94 \%)$ senser roles and 8 sayer $(40 \%)$, and 6 carrier (17.64\%) roles. He has projection in other roles as well, but his involvement in the actor role is dominant. His projection as a goal is $(5=13.51 \%)$; he is the beneficiary and enjoys the role of recipient $(2=28.57 \%)$, and receiver $(2=22.22 \%)$.

The main role Mumtaz is involved in, is actor (36.17\%). She is identified in two processes (clauses $77 \& 82)$. She feels, acts, says and behaves like active males. Her economic role as a journalist, though mocked, can be observed here. This is in contrast with stereotypical roles of women as mother, wife and sister, etc. The verbal processes connected to Mumtaz present an intimacy between Daru and Mumtaz. She is sender while Daru is the receiver of her messages silently. The verbiages (in the pattern of long stretches of speeches) associated with Mumtaz show that she shares secrets of her life with Daru which she avoids to share with Ozi. The clause (She says with a grin) shows her intimate and friendly attitude towards Daru. The mental processes indicate self-expression and self-revelation of her character, and adventurous and restless soul.

Text-G contains 117 clauses, 221 processes, 87 actors, 64 goals, 8 beneficiaries, 23 sensers, 22 phenomena, 26 carriers, 6 possessors, 20 sayers, 7 receivers, and 7 behavers. The major participants are Daru, Mumtaz, Dilaram, and Landlord. Daru is projected as actor $(16.09 \%)$, goal $(6.68 \%)$, senser $(47.82 \%)$, phenomenon $(9.09 \%)$, carrier (7.69\%), sayer (10\%) and behaver (14.28\%). Daru and Landlord have been associated with more material processes, which suggest the patriarchal ideology where males are doer of actions; their experiences are viewed as standard. The frequency of actor role for Mumtaz is (22.98\%). Dilaram has projection of actor role in 20 (22.98\%) clauses, goal in $4(6.25 \%)$, beneficiary in one (12.5\%), senser in $7(30.43 \%)$, carrier role in $5(19.23 \%)$ clauses, sayer in one (5\%) and receiver role in only one clause (14.28\%).

The material processes exceed other types in both the characters of women. They help in revealing the power relations of Pakistani women as power is exerted within the domain of "doing" rather than "saying", "sensing", or "behaving" and physical force influence how they act (Poynton, 1989). Through the more active roles to the women participants, the writer has tried to give feminist ideology and project the image of Pakistan as a liberal state. Associated processes suggest the typical female roles. For example (Dilaram chuckles, Dilaram laughs solidly her body rippling, I poisoned him, she laughs silently shuddering, she smiles at our adolescent tea server, who smiles and lowers her gaze politely, and then she points one henna-decorated finger at me, She wears bells on her ankles that chime as she walks, this is the only service she's made to provide, But she does it for me).

Text-H consists of 31 complex and 49 simplex clauses, and 108 participants associated with 83 processes. The frequency of clauses is: material $(51=61.44 \%)$, mental $(4=4.81 \%)$, verbal $(4=4.81 \%)$, and relational $(24=28.91 \%)$. Total roles are: actors $=33$, goals $=31$, beneficiaries $=3$, sensers $=3$, phenomena $=3$, carriers $=19$, possessors $=3$, sayers $=4$, receiver $=1$, possessed $=3$ and attributes $=20$. Daru is projected as actor in $(3=9.09 \%)$ processes, and carrier in $(2=10.52 \%)$ processes.

Text-I consists of 62 complex and 66 simplex clauses. The projection of material clauses is $(60=57.14 \%)$, mental 
$(6=5.71 \%)$, verbal $(20=19.04 \%)$, and relational $(18=17.14 \%)$ and one behavioural process. Total actors are 43 : goals $=27$, beneficiaries $=2$, sensers $=4$, phenomena $=5$, carriers $=15$, sayers $=18$ and receivers $=8$. Daru is most often projected as taking up the role of actor $(20.93 \%)$, goal $(14.81 \%)$, senser $(75 \%)$, carrier $(20 \%)$, sayer $(27.77 \%)$ and receiver (37.59\%). The main role given to Ozi is that of actor (16.27\%). His involvement in other roles is marginal. Mumtaz is involved in actor role (19.84\%), and sayer (27.27\%). Text-J possesses 13 complex clauses, 15 simplex clauses, 49 processes and 47 participants. The projection of mental (12.24\%), verbal (4.08\%) and relational $(10.20 \%)$ clauses, is minimal. The existential and causative processes are absent from this text. The major participant roles are associated with Daru and Mumtaz.

Text- K contains 71 complex, 77 simplex clauses, 137 participants and 97 processes. The frequency of clauses is: material $(42=43.29 \%)$, mental $(22=22.68 \%)$, verbal $(10=10.30 \%)$, relational $(21=21.64 \%)$ \{Attributive $14=66.66 \%$, relational identifying one $=4.74 \%$, and relational possessive $6=28.57 \%\}$. The major participants are Ozi, Daru and Mumtaz. Daru is positioned as an actor in 10 processes, as a goal in 2, as a sayer in 5, as a carrier in one, as a senser in 4 processes, while Ozi has more projection as a senser 13 processes. Daru acts in clauses (1i, 1ii, 2i, 23, 36, 57, 58, 68ii, 60, 61, 64, 67ii). The verbiages in clauses (3i, 5, 6, 8, 10, ii, 12, 13, 14, 15, 16, 17, $18,20,22,23,24,26,29,31,34,35,41,44,53,54,56,58,60,62,64,65,67)$ are associated with Ozi. They show authority and role of power through language. Ozi's thoughts and mental states have more representation in clauses 5, 6, 8, 9, 19,20,29,34, 37, 38, 44, 66 (e.g. he thinks, he feels, he does not know, he thinks, then he thinks, he does not know, he knows, he does not like, he discovered, he knows, he hopes, he thinks, he wonders). The projection of Mumtaz is minimal. She is involved only in carrier role in seven processes. The attributes in clauses 5, 9, 12,13, 17, 27, 30 (she is unhappy, she is unhappy, she is always tired, she is Spanish, she was like this, she probably is, she has been like this) show the character of Mumtaz. These are gender based attributes which show the woman's traditional character (being always tired, unhappy and complaining, not liking anything). Her association with mental processes in clause 11, 17 and 18 shows her inner feelings. She is sayer in two processes, which shows the stereotype of the society that the woman should keep silence and obey men, speak less and listen more as the male has the power to say not the female.

Text-L contains 17 sentences, 60 participants, and 42 processes in 19 simplex clauses. It has $(22=52.38 \%)$ material, $(4=9.52 \%)$ mental, $(9=21.42 \%)$ relational, $(4=9.52 \%)$ verbal, and $(3=7.14 \%)$ behavioural processes. There are 14 actors, one agent, 15 goals, one beneficiary, 4 sensers, 5 phenomena, 8 carriers, one possessor, two behavers, two receivers, and 3 sayers. The major participant is Murad. Text-M consists of 11 simplex clauses, 36 processes $(19$ materials, $(10=27.77 \%)$ relational and $(16.66 \%$ mental). The analysis of Text-N shows that there are 39 sentences, 48 simplex clauses, 77 processes and 112 participants. Material $(42=54.54 \%)$ processes are dominant in the text. The text has 32 actors, 15 goals, 2 beneficiaries, 2 ranges, 8 sensers, 9 phenomena, 8 carriers, 12 sayers, and 4 receivers. Daru is associated with more participant roles (actor $43.75 \%$, goal $6.66 \%$, beneficiary $50 \%$, sayer $41.66 \%$, receiver $25 \%$, and senser $62.5 \%$ ).

Text-O possesses 22 sentences, 30 simplex clauses and 54 participants. The processes are as follows: material $(17=39.53 \%)$, relational $(16.27 \%)$, and verbal $(6=13.95 \%)$. It has 10 actors, 9 goals, 4 beneficiaries, 13 sensers, 8 phenomena, 6 carriers, one token and 5 sayers. The major participants are Mumtaz and Ozi. Mumtaz has a projection of actor role (60\%), goal (22.22\%), sayer (40\%), senser $(69.23 \%)$, and carrier (50\%). Text-P contains 16 sentences, 24 clauses and 40 processes. It has 9 actors, 4 goal roles, one beneficiary, 10 sensers, 9 phenomena, 2 behavers, and 10 carriers. The major participants are Daru and Mumtaz. Mumtaz has more projection in actor role (55.55\%). Material and mental processes depict her relationship with Daru. Clauses 1i, 1ii, 2, 3i, 3ii, 3ii, 4, 6, 7i, 7ii, 7iii, 8i, 8ii, 12 and 16 show her liberal role and the reason of her being attracted to Daru. The clauses (when I met Darashikoh Shezad, I did not know whether I was going to sleep with him, but I knew I wanted to, he seemed perfect partner, I knew he'd keep his mouth shut, sex was a revelation, my affair with Daru was the most liberating experience, I felt bad, selfish, I also felt good) show a great deal of consciousness and feelings in her character.

In text-O, Mumtaz is given much more senser role as compared to her role in the previous texts. For example (she did not know, knew, wanted, knew, knew, realized, knew, felt, felt. These processes show Mumtaz's thoughts, feelings, her consciousness and present -mindedness about her environment. Clauses 13 and 15 (I felt bad, and I also felt good) show two sides of human beings, good and bad. The relational clause (he was smart $n$ sexy) reveals Daru's external as well as internal states. Similarly, the clause (he would keep mouth shut) gives reason for Mumtaz's relying on Daru and expresses her thinking and confidence. Daru is associated with the carrier role in $(4=40 \%)$ processes. The attributes in clauses (the perfect partner, smart and sexy, fantastic) show his masculinity and manliness.

Text-Q contains 29 sentences, 31 clauses, 70 participants and 54 processes. The frequency of material clauses is 
$(23=2.49 \%)$, relational $(27.77 \%)$, and verbal $(4=7.4 \%)$. There are 18 actors, 13 goals, 9 sensers, 7 phenomena, 11 carriers, one token and 2 sayers. Daru and Mumtaz dominate as the major participants. Daru is projected as actor $(38.88 \%)$, sayer $(100 \%)$, senser $(88.88 \%)$ and carrier $(9.9 \%)$. Mumtaz has projection of actor $(16.66 \%)$, goal, (23.07\%), senser (11.11\%), and phenomenon (14.28\%). Daru acts in clauses 1, 4, 6, 7, 9 and 26. Much importance is given to his actions and states. Daru is shown here as a man of love. He is so mesmerized by her beauty that he knows even the minute details of her body parts. "Touching her, calling her, kissing her and even thinking her" make him happy. He not only loved Mumtaz, but he loved the idea of love between them. He loved heroin as he was addicted to it though he was well aware of its bad effects on life. The clauses (May be even a little heroin, I tried heroin) depict his addiction with heroin as well as obsession with the heroine of the novel. The projection of Mumtaz with carrier role, having attributes related to her body parts (lips, skin, jaw, neck, moles, her ear, her hip, trough of the wave, pelvis etc.) shows that Daru as a male makes survey of her body. His actions of gazing in detail are sanctioned in the male-dominated society. The attributes referred to the physical beauty of female reflect the gender bias attitude of patriarchal society of Pakistan.

Text-R includes 40 sentences, 56 clauses, 120 participants, 80 processes (material (43.75\%), relational (35\%), mental (12.5\%), verbal (2.5\%), behavioural (1.25\%) and existential (5\%)). It has only 2 actors, 25 goals, 4 beneficiaries, 11 sensers, 8 phenomena, 20 carriers, and 3 tokens. Ozi is dominant as a participant. His projection as an actor and senser is minimal. His major role is found in relational processes. He is agent in clause 4 . The clauses (I'm Aurangzeb;; I'm not a bad guy; I'm wealthy, well connected, and successful, be an important person; 'm his money launderer; am really not that bad, wealthy, well connected, and am successful) describe what he actually is and what he is taken by other characters of the novel. Hamid's narrative needs a vigilant reader. Clauses (23-32) also assign -er or doer role to "you" the reader. They show active participation of the reader.

Text-S presents 79 sentences, 83 clauses, 144 participants, 101 processes and 67 circumstances. The (56=55.44\%) material processes outnumber other processes. The next highest frequency is found in $(26=25.74 \%)$ relational clauses. Total number of actor roles is 46 . The major participant roles are associated with Daru and Mumtaz. Daru has projection of actor roles $(41.30 \%)$, goal $(26.92 \%)$, senser $(46.15 \%)$, and carrier $(32 \%)$. Through material and mental processes, Daru narrates his internal state of mind and heart. The clauses (He feels a strange yearning, the hunger of a man fasting, not because he believes, but because he is ashamed, not the cleansing hunger of the devout, but the feverish hunger of the hypocrite) show that he is overwhelmed by the feeling of hunger (hunger for food, hunger for drugs and hunger for Mumtaz).

Mumtaz's feelings and thoughts are presented in clauses 2, 6, 31, 32, and 41. Her actor role is projected in clauses $8,12 \mathrm{ii}, 14,24,25,30,38,39,41,52,57,60,63,74$, and $79 \mathrm{i}$. It can be observed that her actions involve Daru and her self-being and the goals of the processes associated with her are her body parts. She affects her body parts like her head, her hair, and her lungs while she inhales, her legs while walking, her toes, and Drau's body while kissing him.

She proves herself as a passionate, loving woman and dynamic actor. She is carrier in clauses (she is quiet for a moment, I am not really not at all that nice, am the sort who should marry, I'm a bad wife, I' $m$ a worse mother, I'm flawed, Mumtaz is with me, she has the long torso). These clauses include gender bias attributes attached to Mumtaz. Certain lexical items i.e., negative adjectives like bad wife, worse mother, bad design, flawed, etc. convey, on the one way, the feelings and realization on the part of Mumtaz and on the other hand, show the depiction of a woman, and attitudes and norms of behaviour present in Pakistani patriarchal society. She is depicted as an obsessive lover rather a responsible and caring mother. It also shows the mindset of some modern Pakistani girls who don't like to be mothers only for the sake of their personal comfort and commitment.

Text-T contains 38 sentences, 88 simplex clauses, 103 participants, 88 processes and 45 circumstances. The embedded and non-finite clauses are 9 and 8 respectively. Material processes are used with highest frequency $(53.40 \%)$. The projection of mental processes is $(14=15.90 \%)$, verbal processes $(5=6.81 \%)$, and relational $(16=18.18 \%)$. The distribution of roles among characters is: 31 actors, 26 goals, 2 beneficiaries, 10 senser roles, 11 phenomena, 14 carriers, 4 tokens, one possessor, one behaver, 4 sayers and 2 receivers. The major participants are Daru and Mumtaz. Daru is projected as actor $(14=45.16 \%)$, goal $(23.07 \%)$, sayer $(50 \%)$, senser $(80 \%)$, and carrier $(36.36 \%)$ while Mumtaz's projection as actor is $(29.03 \%)$, goal $(19.23 \%)$, beneficiary $(50 \%)$, senser $(20 \%)$, phenomenon $(27.27 \%)$, carrier (9.09\%), token (50\%) and sayer (25\%). Daru acts in clauses 5, 6, 8i, 8ii, 9, $20,28,29,30$, and 33 . He is senser in clauses $8 \mathrm{ii}, 9,18,28,30,32$ and 33 . He is carrier in clauses 2, 12, and 29. Mumtaz's role as actor can be seen in clauses 7, 9, 10, 14, 15, 16 and 17.

The material and mental clauses present her character as a sensitive woman. The clauses (She can keep away and is forced to keep her distance) reveal some conflict in her mind. It shows that she is unable to keep herself from 
Daru. Some clauses focus on her act of body. Daru compares himself with her beloved, and Mumtaz with a moth which, literally, means an insect that revolves around the candle's smoke, flittering flames. The moth loves candle light and sacrifices its life in getting nearer to candle light. Mumtaz is like a candle around which Daru and Ozi circle. The clause (smell of something is burning) shows the active role of non-human character "smell" that provides an effective image of self-destruction and death, the end of Daru's love and life.

In Text-U total number of sentences is 60 , participants 185 , processes 130, and circumstances 79 . It consists of 51 actors, 31 goals, 8 beneficiaries, 23 sensers, 24 phenomenon, 20 carriers, 11 sayers and 5 receivers. The major participants include Daru, Mumtaz and Ozi. This text registers Mumtaz's actions, perceptions, feelings, nostalgia, and the regrets about her past life. She is projected as an actor $(41.17 \%)$, as a goal $(12.90 \%)$, as a senser $(86.95 \%)$, as a phenomenon $(8.33 \%)$, as a carrier of attributes $(35 \%)$, as a sayer $(36.36 \%$ and once $(20 \%)$ as a receiver of verbiage. She has more active roles as an actor and senser. The reason is that she is the center of narration and this is the last time when she ultimately expresses her thoughts with some detail and clarity (see detailed analysis in Qasim, 2016).

\section{Findings and Discussion}

Following is the summary of the discussion of a great amount of text in terms of circumstance, process and participant roles. The discussion starts to see how transitivity has an overall impact on the characters of the novel. The focus of the discussion is three characters, namely, Daru, Ozi, and Mumtaz. The analysis is aimed at seeing how these characters are constructed across different points of view and ideology embedded by the author.

After analyzing the data comprising 21 texts individually, it is concluded that there are 1100 sentences and 1331 clauses in the texts selected from Hamid's novel MS. Apart from the main, subordinate and coordinate clauses, there are 314 embedded and 176 non-finite clauses in the given data. They have their own values as they are constituents of a sentence in terms of circumstantial elements. They expand the meanings of the main clause by providing circumstantial features like time condition, concession, thus enhancing the message (Downing \& Locke, 2006, p. 209). They are used as the "means of syntactic compression" (-"ing" or -"ed" forms or "to-infinitive" which function as the predicate and the subject is omitted but recoverable from the context (Quirk, 1972, p. 727). The nominal or relative clauses are controlled by verb while they are independent and do not have a dependency on any constituent of the main clause.

As noted in the figure-1, all types of processes are found in MS. Based on the rank of frequency, material processes are computed the most frequent processes. They have a frequency of occurrence as $(51.45 \%)$. The projection of mental processes is $(13.91 \%)$ in the second position. The verbal processes are $(11.23 \%)$, relational processes $(19.75 \%)$ while the lowest projection is found in behavioural $(2.63 \%)$ and existential $(0.86 \%)$ processes.

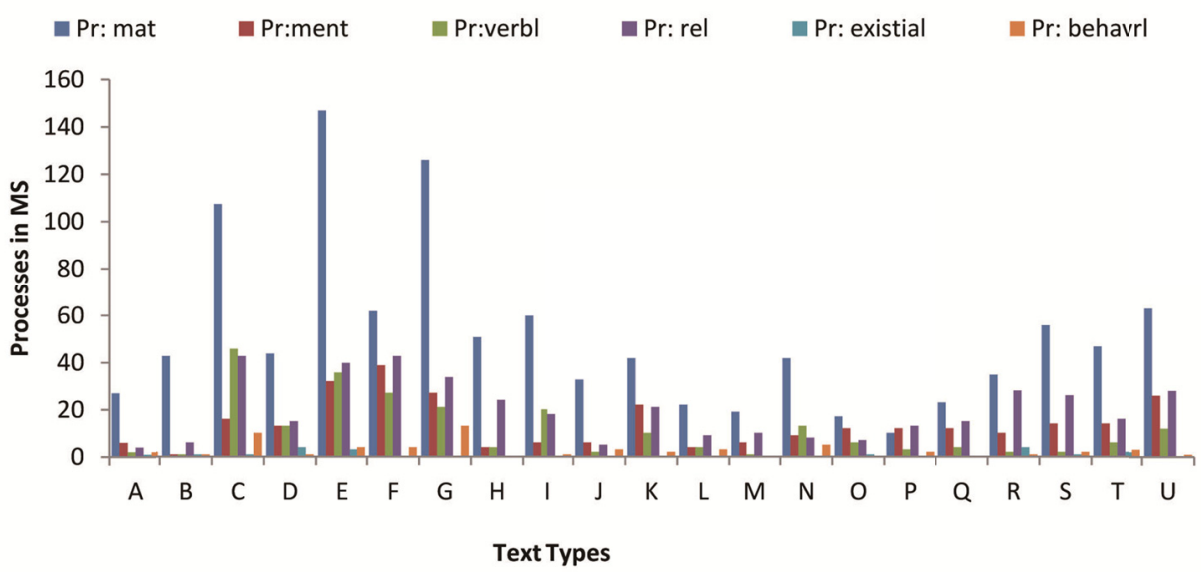

Figure 1. Summary of the occurrence of processes in $M S$

Note $\operatorname{Pr}=$ Process, Pr: mat $=$ material, Pr: ment $=$ mental, Pr: behavioural $=$ behavioural, Pr: verbl $=$ verbal, Pr: existial $=$ existential, Pr: rel= Relational.

The statistical participant analysis has been revealed in figure-2. The presentation of participant roles in $M S$ is 3024. Actor is found with $(721=23.84 \%)$ occurrences. The participant in the form of personal pronoun (I) or 
noun is found mostly involved as actor. It refers to Daru. The frequency of goals in $M S$ is $(601=19.94 \%)$, while recipients are counted $(43=1.42 \%)$. The occurrence of beneficiary is $(36=1.19 \%)$. The element of range occurs ( $26=0.85 \%)$. The novel has $(330=10.91 \%)$ carriers, $(326=10.78 \%)$ attributes, $(14=0.46 \%)$ tokens or identifiers, and $(14=0.46 \%)$ values or identified. There are $(55=1.81 \%)$ possessors, $(48=1.58 \%)$ possessed, $(261=8.63 \%)$ sensers, $230=7.60 \%)$ phenomena, $(34=1.12 \%)$ behavers, $(201=6.64 \%)$ sayers, $(17=0.56 \%)$ existents and $(65$ $=2.14 \%$ ) receivers in the selected texts of the novel.

By exploring $M S$ through the transitivity functions, the study examined the characters' participation in different process types and investigated how their actions affected the characterization and the narrative. Investigation of the main characters in the novel confirms that they are mostly involved in behavioural or material processes. Their actions are not limited to them; they are assigned power of altering or impinging their surroundings. They also occur as participants in mental and verbal processes.

Daru is found the most common participant in material processes along with great frequency of circumstances of location, manner and cause. He has been constructed as the most active participant. Most of the character roles revolve around his magical entity. The material processes associated with him occur with goals, which also reflect his physical movements. Some of them have psychological implications to reflect his cognitive aspects. Further, mental processes indicate that participants are thinkers who remember everything around them. The investigation of Daru's role establishes that his participation can be explored in two ways, depending on whether we emphasize his role as actor or observer. His observation as a narrator is "satisfactory" in terms of portraying his frequent involvement in mental processes. His participation as a leading character is compared to what one might expect from him. The investigation of Ozi has confirmed a sort of "limited" involvement in the phenomenon, as compared to Daru and Mumtaz. He is involved as an actor only in (39=5.40\%) processes. While Daru's roles as a main character is found frequently involved in all the processes, i.e. goal (7.13\%), beneficiary and recipient (13.2\%), senser (14.16\%), carrier of attributes and identified or token (14.24\%), sayer (21.89\%) and behaver $(26.47 \%)$. His frequent participation in goal-oriented processes signifies his ability to make an impact on other entities and surroundings. He also acts as sayer who voices and affects others. Ozi is associated with goal, behaver, senser, carrier and token roles. In contrast, the processes associated with Mumtaz are mainly passivized.

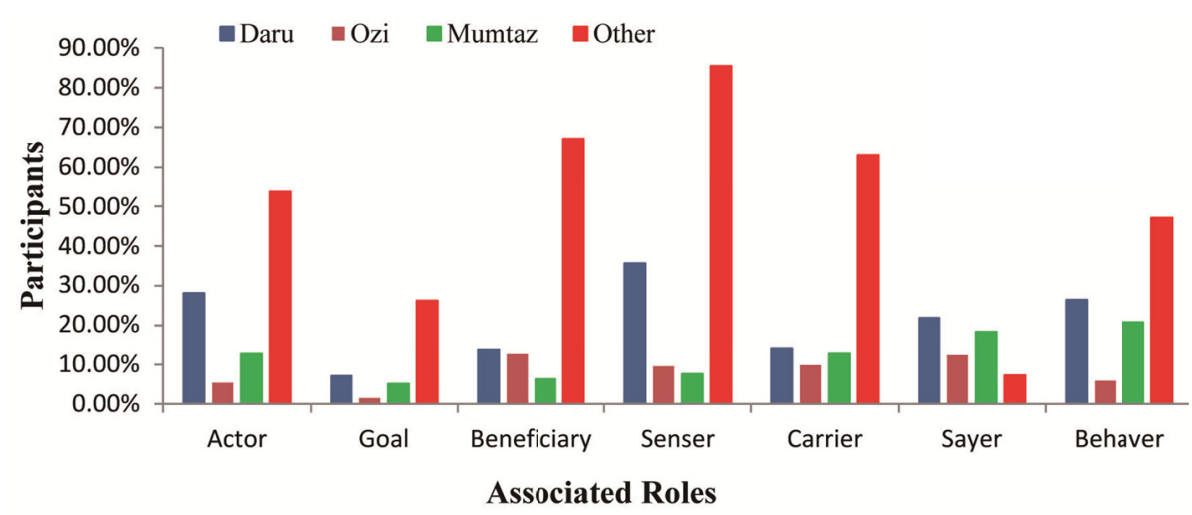

Figure 2. Summary of participant roles in $M S$

Though process-participant configuration is considered responsible for constituting the nexus of transitivity structure, the circumstantial segments are no less important, as they impinge the nexus. They involve almost all the processes. Figure-3 presents the summary of occurrence of circumstances in all the selected texts of $M S$. According to it, 1128 circumstances find a place in the extracts. The circumstances of temporal and spatial location $(49.64 \%)$ are dominant over all circumstances. Frequency associated with other circumstances is as follows: manner $(27.65 \%)$, cause $(10.37 \%)$, accompaniment $(4.43 \%)$ extent $(3.01 \%)$, role $(1.59 \%)$, matter $(1.86 \%)$, contingency $(1.24 \%)$, and angle $(0.17 \%)$. 


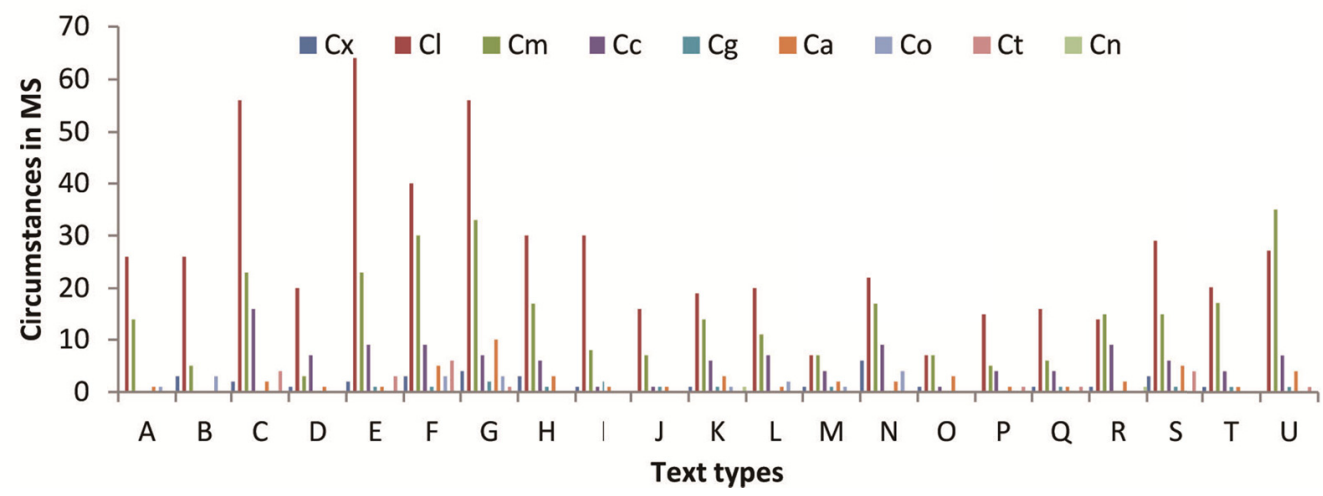

Figure 3. Summary of circumstances in $M S$

Note. 1) Cx: Circumstance of Extent, 2) Cl: Circumstance of Location, 3) Cm: Circumstance of Manner, 4) Cc: Circumstance of Cause, 5) Cg: Circumstance of Contingency, 6) Ca: Circumstance of Accompaniment, 7) Co: Circumstance of Role, 8) Ct: Circumstance of Matter, 9) $\mathrm{Cn}$ : Circumstance of Angle

The study has also sought to demonstrate how experiential ideational and ideological meanings are constructed by foregrounding some specific linguistic features. The extracts of the novel offer evidence regarding the roles of the participants and the relation of lower class with the upper, the subordinate with the boss and, of female with male (Manucci and Daru, Daru and Ozi, Daru and Malik Jiwan, Daru and Bank Manager, Dilaram and landlord). The nuclear participants associated with relational processes and metaphors provide a detail about their multifaceted identity which reveals their role, class, social status, physical attributes etc.

Male characters share some features. They outnumber in role relations while females have less participation. The high amount of actor description used for Daru as the protagonist of the story is ideological in favour of antifeudalism and anti-corrupt system characters. Most frequent material processes are associated with the males. They take actions and initiatives. They affect the phenomenon and take control of what is happening in the story. They are doer of more practical actions, indulged in rational matters, and have clear goals than females. The author has proved their capacity to do work publically. The males act more while the females perceive more. For instance, Daru is involved as an agent in goal-directed processes and influences others. He takes control of the whole phenomenon. The contrast between male and female characters portrays the gender relations and ideologies, and stereotypically present in the novel.

The males act as sayer in verbal processes. Ozi is mainly involved in more relational and verbal processes. He is an identified and extra ordinary person who has power to voice. It means the things are done to the ladies who are cast in passive and helpless roles. They are involved in internalized and passivized processes and emotional, linguistic choices in mental processes, and do not affect other participants and external events.

In contrast, Mumtaz has complex power relations with her husband, Ozi and her lover, Daru. Unlike Dilaram and other Pakistani female participants in the novel, she has been portrayed as a powerful lady who affects other characters through her actions. She has all types of processes. She is the challenge to the stereotypical Pakistani women. Gender roles like working for men and helping them (e.g., crumble the hash into the tobacco, crushing it, breaking it, kneading) are associated with women. These processes show negativity of feelings against females. The attributes in relational clauses like (stick, beautiful, not very sexy, has hoarse voice' not bad-looking, skinny, soft voice, pretty girl, boobs are bigger than they were. I've I a boy, you have broad shoulders, they seem small, her voice is throaty, pregnant, woman with finely plucked eyebrows, fleshy body, well-proportioned and voluptuous, a nice face. good hips, your breasts aren't generous, young girl with long eyelashes, she turns and kisses me on the cheek, her hand curling around the back of my head, touching my neck and my hair, leans away from me and smiles, flashes a sly grin, am in Heera Mandi, made me have sex with men, black lump on her face, always unhappy, always tired, is Spanish, so stunningly regal, her hair like a tiara on her head, and her navel) express weakness, socially lower status, gender stereotypes, intimacy, appearance, physical structure, identity and femininity of female characters. These attributes demonstrate their negative aspects while males are presented as dynamic and romantic characters. Mental processes associated with the females portray their feelings and worries (affection, intimacy, honour, safety, home, husband and children) and males' thoughts about practical and public matters. The involvement and interaction of Mumtaz and Dilaram with the male participants prevent them to be powerful figures. The relationship of Mumtaz with Daru stresses their 
sentimental and dominated position. Mostly they rely on the males for their success. Some extracts describe women both as active and passive in their relationship with male persons.

The selected texts also show the reversal of conventional gender roles in case of Mumtaz and Dilaram. They realize that they should be as powerful as the males and for this purpose they are involved in dynamic, economic and social activities. Mumtaz acts as a secret investigative reporter, adopts the pen name (interestingly male person, Zulfikar Manto) to raise the suppressed voices of the depressed and discusses the taboos and Dilaram earns money by running a brothel. The contrast among male and female characters portrays the gender stereotypes, ideologies and construct of the society Hamid lives in.

\section{Conclusion of the Study}

The transitivity analysis of the texts shows how skillfully Hamid has employed the linguistic choices to convey the meanings to the readers. The characters are perceived what type of persons they are by knowing what type of participant roles are ascribed to them. It has been demonstrated that other factors such as the attitude of a narrator, the situations and circumstances in which a character is cast, and the thematic concern of the novel also complement rather mediate between point of view and transitivity choices that are associated with a character. The study also shows that three characters are most frequently assigned agency in processes, irrespective of point of view. The material processes show prominence of information falling on events which indicates that the descriptions in the text are concrete rather than idealized.

It has been proved that transitivity system is a reliable tool for understanding literary works and style of the author (Halliday, 1971; Kennedy, 1982; Silva, 1998; Ji \& Shen, 2004, 2005; Iwamoto, 2007; Rodrigues, 2008). Thus the study provides a new perspective to understand the work of Hamid and to appreciate his style.

\section{Recommendation}

Only ideational system from Systemic Functional Grammar was applied for understanding the meanings of a literary text. Interpersonal and textual systems can be applied to address the thematic and textual functions of the novel. This study was concerned only with fiction and same approach can also be applied to other genres.

\section{References}

Cap, P., \& Okulska, U. (Eds.). (2013). Analyzing Genres in Political Communication: Theory and Practice (Vol. 50). Amsterdam: John Benjamins Publishing. https://doi.org/10.1075/dapsac.50

Creswell, J. W. (1994). Design Qualitative, Quantitative and Mixed Methods Approaches (2nd ed.). London: SAGE Publications.

Dang, E., Zholi, I., Kerluk, L., Cruz, M., \& Zhan, X. (2015). Reflection on the Tension of Daru's Love. Retrieved from http://mothsmokes-blog.tumblr.com/

Desai, A. (2000). Passion in Lahore. Retrieved from http://www.nybooks.com/articles/archives/2000/dec/21/passion-in-lahore/?pagination=false

Devrim, D. Y. (2015). Grammatical Metaphor: What do we mean? What exactly are we researching? Functional Linguistics, 2(3), 1-15. https://doi.org/10.1186/s40554-015-0016-7

Downing, A., \& Locke, P. (2006). English Grammar: A University Course. London \& New York: Routledge.

Droga, L., \& Humphrey, S. (2003). Grammar and Meaning: An Introduction for Primary Teachers. Australia: Target Texts.

Eggins, S. (2004). An Introduction to Systemic Functional Linguistics (2nd ed.). New York \& London: Continuum.

Fowler, R. (1986). Linguistic Criticism. Oxford: Oxford University Press.

Fowler, R. (1986). The Language of Literature. London: Rutledge \& Kegan Paul.

Gallardo, B. C. (2006). Analysis of a Literary Work using Systemic Functional Grammar. 33rd International Systemic Functional Congress. Retrieved http://www4.pucsp.br/isfc/proceedings/artigos\%20pdf/351_gallardobarbara_735a762.pdf

Gehr, R. (2000). Nuclear Burnout. The New York Village Voice. Retrieved from http://www.villagevoice.com/2000-01-25/books/nulear-burnout/

Gerot, L., \& Wignell, P. (1994). Making Sense of Functional Grammar (p. 74). Sydney: Gerd Stabler.

Greenwood, D. V. (2000). Hamid's Debut Burns Brightly. Retrieved from 
http://weeklywire.com/ww/05-15-00/boston_books_2.html

Haig, E. (2012). A Critical Discourse Analysis and Systemic Functional Linguistics Approach to Measuring Participant Power in a Radio News Bulletin about Youth Crime. In Studies in Media and Society, 4, 45-73. Retrieved from lang.nagoya-u.ac.jp

Halliday, M. A. K. (1971). Linguistic Function and Literary Style: An Inquiry into the Language of William Golding's the Inheritors. In S. Chatman (Ed.), Literary Style: A Symposium (pp. 330-368). New York: Oxford University Press.

Halliday, M. A. K. (1976). System and Function in Language (Ed.by G. R. Kress). Oxford: Oxford University Press.

Halliday, M. A. K. (1985). An Introduction to Functional Grammar. London: Edward Arnold.

Halliday, M. A. K., \& Matthiessen, C. M. I. M. (1994; 2004). Introduction to Functional Grammar. London: Edward Arnold.

Halliday, M. A. K., \& Matthiessen, C. M. I. M. (2004). An Introduction to Functional Grammar (3rd ed.). London: Hodder Arnold.

Hamid, M. (2001). Moth Smoke. London: Granta Books.

Hasan, R. (1986). The Ontogenesis of Ideology: An Interpretation of Mother-Child Talk. In M. A. K. Halliday (1971, Ed.), Linguistic Function and Literary Style: An Enquiry into the Language of William Golding's "The Inheritors". In S. Chatman (Ed.), Literary Style: A Symposium (pp. 362-400). New York: Oxford University Press, 362-400.

Hasan, R. (1988). The Analysis of One Poem: Theoretical Issues in Practice. In D. Birch \& M. O’ Toole (Ed.). Functions of Style (pp. 45-73). London: Pinter.

Hasan, R. (2011). Selected Works of Ruqaiya Hasan on Applied Linguistics. China: Foreign Language Teaching and Research Press. Retrieved from http://mothsmokes-blog.tumblr.com/post/101772936881/reflection-on-the-tension-of-darus-love

Iwamoto, N. (2007). Stylistic and Linguistic Analysis of a Literary Text using Systemic Functional Grammar. (Online). Retrieved from http://human.kanagawau.ac.jp/gakkai/publ/pdf

Jay, P. (2005). The Post-Post-Colonial Condition: Globalization and Historical Allegory in Mohsin Hamid's Moth Smoke. Ariel, $36(1-2)$. Retrieved from http://www.ariel.ucalgary.ca/ariel/index.php/ariel/issue/view/31

Ji, Y., \& Shen, D. (2004). Transitivity and Mental Transformation: Sheila Watson's The Double Hook. In Language and literature, 13(4), 335-348. https://doi.org/10.1177/0963947004046284

Ji, Y., \& Shen. D. (2005). Transitivity, Indirection, and Redemption in Sheila Watson's the Double Hook. In Style Fall 2005, 3(39), 348-362. Retrieved from www.style.niu.edu/vol39n3.htm

Kazemian, B., \& Hashemi, S. (2014). Critical Discourse Analysis of Barack Obama's 2012 Speeches: Views from Systemic Functional Linguistics and Rhetoric. Theory and Practice in Language Studies (TPLS), 4(6), 1178-1187. https://doi.org/10.4304/tpls.4.6.1178-1187

Kazemian, B., \& Hashemi, S. (2014). Nominalizations in Scientific and Political Genres: A Systemic Functional Linguistics Perspective. International Journal of Humanities and Social Sciences, 3(2), 211-228.

Kazemian, B., \& Hashemi, S. (2017). A Radical Shift to a Profound and Rigorous Investigation in Political Discourse: An Integrated Approach. International Journal of English Linguistics, 7(3), 115-128. https://doi.org/10.5539/ijel.v7n3p115

Kazemian, B., Behnam, B., \& Ghafoori, N. (2013). Ideational Grammatical Metaphor in Scientific Texts: A Hallidayan Perspective. International Journal of Linguistics, 4(4), 146-168. DOI:10.5296/ijl.v5i4.4192

Kennedy, C. (1982). Systemic Grammar and its use in Literary Analysis. In R. Carter (Ed.), Language and literature: An Introductory Reader in Stylistics (pp. 82-99). London: George Allen and Unwin.

Kharal, A. A. (2008). Humanism in Pakistani Novels in English from 1985 to the Present. Unpublished thesis PhD. Islamabad: National University of Modern Languages.

Kinga (2011). Mohsin Hamid- Moth Smoke. Review. Retrieved from http://kinga-thebooksnob.blogspot.com/2011/11/mohsin-hamid-moth-smoke.html 
Lahiri, J. (2000). Money talks in Pakistan. The New York Times. Retrieved from https://www.nytimes.com/books/00/03/12/reviews/000312.12lahirit.html

Martin, J. R., Matthiessen, C. M. I. M., \& Painter, C. (1997). Working with Functional Grammar. London: Arnold Publishers.

Matthiessen, C. M. I. M., \& Halliday, M. A. K. (1997). Systemic Functional Grammar: A First Step into the Theory. Sydney.

Mwinlaaru, I. N. (2012). A Stylistic Study of Characterization and Point of View in Chinua Achebe's Anthills of the Savannah: A Functional-Semantic Perspective. Unpublished Masters' Thesis. University Cape Coast.

Mwinlaaru, I. N. (2012). Transitivity and Narrative Viewpoint in Ngugi Wathiong's weep Not, Child. In Dora F. Edu-Buandoh \& Anita B. Appartaim (Eds.), Between Language and Literature: A Festschrift for Professor Kofi Edu Yankson (pp. 354-370). Cape Coast: Cape Coast University Press.

Noor, M., Ali, M., Muhabat, F., \& Kazemian, B. (2015). Systemic Functional Linguistics Mood Analysis of the Last Address of the Holy Prophet (PBUH). International Journal of Language and Linguistics, 4(1-1), 1-9. https://doi.org/10.2139/ssrn.2604000

Pande, I. (2000). Strange Love in Lahore: Old histories, new crises--and that deathly N word. Retrieved from http://archives.digitaltoday.in/indiatoday/20000501/books.html

Perner, C. (2011). Tracing the Fundamentalist in Mohsin Hamid's Moth Smoke and The Reluctant Fundamentalist. In ARIEL: A Review of International English Literature. Calgary: University of Calgary press.

Poynton, C. (1989). Language and Gender: Making the difference. Oxford: Oxford University Press.

Qasim, H. M. (2016). A Transitivity Analysis of Mohsin Hamid's Fiction. a PhD Dissertation submitted at Bahauddin ZakariyaZ University, Multan, Pakistan

Quirk, R., \& Greenbaum, S. et al. (1972). A Grammar of Contemporary. English: Longman.

Rangani, D. (2010). The Portrayal of Women as a Shakti- the Power by Anita Desai in Clear Light of the Day and. Retrieved from http://www.imow.org/dynamic/user_files/file_name_268.doc

Rodrigues, A. S. (2008). An Exploratory Study of Representation of Gay Characters in a Parallel Corpus of Short Stories: A Systemic Functional Approach. Retrieved from http://www.periodicos.ufsc.br/index.php/traducao/article/viewFile/6734/6207

Sadiq, U. (2006). Point of View and Speech and Thought Presentation in Mohsin Hamid's Moth Smoke. An M.Phil unpublished thesis, Multan: BZ University.

Samimi, M. R. (2013). A Comparative Quality Assessment of Translation of Faulkner's "Uncle Willy" Based on Halliday's Systemic Functional Grammar Model. In Elixir International Journal Linguistics and Translation: Elixir Ling. \& Trans. 55(2013), 13124-13128. Retrieved from www.elixirpublishers.com

Silva, L. M. (1998). Character, Language and Translation: A Linguistic Study of a Cinematic Version of $A$ Streetcar Named Desire. Cadernos de Tradução, 1(3), 339-368.

Simic, M. (2013). The Treatment of Unactualized Process Participants in English Serbian Translation-Corpus Analysis. An Unpublished Master Thesis: The University of Nis. Retrieved from http://www.filfak.ni.ac.rs/studenti/preuzimanje/radovi/master_radovi/anglistika/rad_milena_simic.pdf

Simpson, G. (2004). Stylistics: A Resource Book for Students. London and New York: Routledge.

Tariq, H. (2008). Class Conflict in Moth Smoke: An Analysis on Mohsin Hamid's Use of Characterization. In International Research Journal of Arts and Humanities (vol. 35). Jamshoro, Pakistan: Faculty of Arts University of Sindh.

\section{Copyrights}

Copyright for this article is retained by the author(s), with first publication rights granted to the journal.

This is an open-access article distributed under the terms and conditions of the Creative Commons Attribution license (http://creativecommons.org/licenses/by/4.0/). 